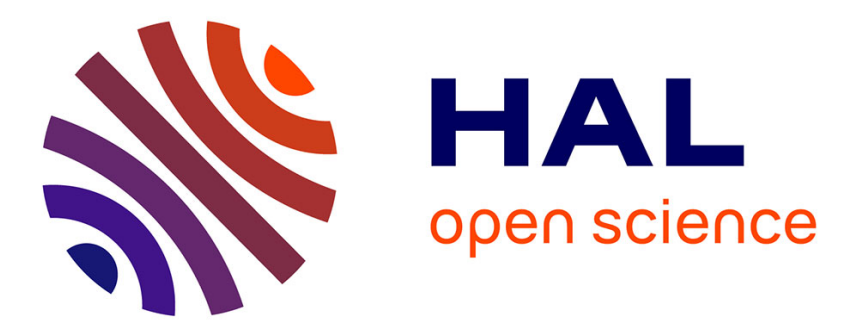

\title{
Aging of Commercial Diesel Oxidation Catalysts: A preliminary Structure/Reactivity Study
}

Y. Xie, E. Rodrigues, N. Furtado, A. Matynia, T. Arlt, P. Rodatz, Patrick da Costa

\section{- To cite this version:}

Y. Xie, E. Rodrigues, N. Furtado, A. Matynia, T. Arlt, et al.. Aging of Commercial Diesel Oxidation Catalysts: A preliminary Structure/Reactivity Study. Topics in Catalysis, 2016, 59 (10), pp.10391043. 10.1007/s11244-016-0586-y . hal-01311530

\section{HAL Id: hal-01311530 \\ https: / hal.sorbonne-universite.fr/hal-01311530}

Submitted on 4 May 2016

HAL is a multi-disciplinary open access archive for the deposit and dissemination of scientific research documents, whether they are published or not. The documents may come from teaching and research institutions in France or abroad, or from public or private research centers.
L'archive ouverte pluridisciplinaire HAL, est destinée au dépôt et à la diffusion de documents scientifiques de niveau recherche, publiés ou non, émanant des établissements d'enseignement et de recherche français ou étrangers, des laboratoires publics ou privés. 


\title{
Aging of Commercial Diesel Oxidation Catalysts: a preliminary
}

\section{Structure/Reactivity Study}

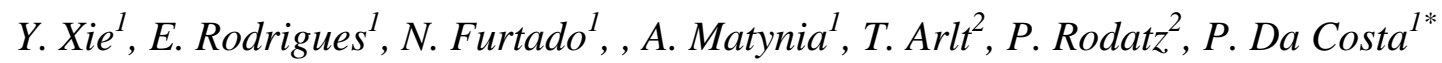 \\ ${ }^{1}$ Sorbonne Universités, UPMC Univ Paris 06, UMR 7190, Institut Jean le Rond d'Alembert, F- \\ 75005, Paris, France. \\ ${ }^{2}$ Continental Automotive GmbH, Siemensstrasse 12, 93055 Regensburg, Germany,
}

Abstract

This study focuses on the catalytic behavior of the Diesel Oxidation Catalyst using different aging characteristics of road mileage in order to improve the efficiency of an ammonia SCR system on an after-treatment line composed by a DOC + DPF + SCR. The studied catalyst is a commercial diesel oxidation catalyst $\left(\mathrm{Pt} / \mathrm{Pd} / \mathrm{Al}_{2} \mathrm{O}_{3}\right)$ provided by Continental. Hydrothermal aging were performed on carrots of monolith in varying the temperature of treatment. These carrots were characterized, X-ray diffraction (XRD), transmission electron microscopy (TEM) coupled by EDS and Specific surface measurement $\left(\mathrm{S}_{\mathrm{BET}}\right)$. The catalytic measurements consisted of series of temperature programmed surface reactions (TPSR). To be close to real driving conditions, our experimental setup comprised a pre-heater in which the gases were heated up to $500^{\circ} \mathrm{C}$. The goal of this study is to understand the evolution of the active phase with the aging and to correlate these aging results with the corresponding overall catalytic activity and their impact on the reactions involved in the DOC with respect to CO, hydrocarbons and NO.

Keywords: NO oxidation, bimetallic DOC, hydrothermal aging, effect of the feed

\section{Introduction}

\footnotetext{
* Corresponding author. Tel.: + 331308548 62; Fax: + 33130854899 .

E-mail: patrick.da_costa@upmc.fr
} 
In order to reduce the vehicle emissions and to reach the actual EURO VI standards, the automotive manufacturers need better understandings of the after-treatment systems. Increasingly stringed regulations for diesel engine emissions have a significant impact on the required efficiency of Diesel Oxidation Catalysts (DOC) since the after-treatment line is now composed by a DOC, a Diesel Particulate Filter (DPF) and a $\mathrm{NO}_{x}$ abatement system $\left(\mathrm{NO}_{x}\right.$ trap or $\mathrm{NH}_{3}$ SCR) [1]. Lowered DOC oxidation efficiency due to thermal aging effects influences the efficiency of the exhaust after-treatment systems downstream of the DOC [2] and mostly on SCR systems.

In this study the behavior of the Diesel Oxidation Catalysts "DOC", composed mainly by noble metals supported on alumina $[3,4]$ is analyzed, in order to develop improvements of the efficiency of an ammonia SCR system on a complete after-treatment line composed by a DOC + $\mathrm{DPF}+\mathrm{SCR}$. It is already known [5] that the control of the $\mathrm{NO}_{2}$ concentration before the SCR system is pretty important, due to the so-called "FAST SCR" reactions.

In this work, the effect of hydrothermal aging on the reactivity and structure of a commercial DOC is investigated as a function of temperature in order to understand what are the chemical reactions affected by the aging versus time on road. Hydrocarbon, $\mathrm{CO}$ and NO oxidation reactions are assessed for catalysts aged at various temperatures and for different gaseous feeds.

\section{Experimental section}

The catalyst used for this study is a commercial DOC catalyst provided by Continental. The catalyst is composed by a bimetallic $\mathrm{Pt} / \mathrm{Pd}(3 / 1)$ phase supported on alumina with a metallic loading of $80 \mathrm{~g} / \mathrm{ft}^{3}$. The first study was performed using a stabilized catalyst $\left(750 \_4 \mathrm{H}\right)$. The aged catalysts are designated by "850_10H", "850_24H" and "950_4H" respectively, because the catalysts have been aged at $750^{\circ} \mathrm{C}, 850^{\circ} \mathrm{C}$ and $950^{\circ} \mathrm{C}$ under different durations $(4,10$ or 24 hours) in $10 \% \mathrm{H}_{2} \mathrm{O} /$ Air. The first two aging temperatures were chosen because they were 
representative of real driving cycles [5] and the last one was selected in order to lead to a severe aging of the DOC. The aging was done using temperature programmed reaction in which water ( $10 \%$ in volume) was injected on the catalyst in a flow of synthetic air (total flow of 19 NL.min ${ }^{-}$ ${ }^{1}$ ). These thermal agings were performed on carrot monolithic catalyst, as described elsewhere [5]. XRD data were recorded on a Bruker Advanced D8 using $\mathrm{CuK} \alpha$ radiation. PXRD measurements were performed from 5 to $90^{\circ}$ in an interval of $1^{\circ}$ with a count time of $6 \mathrm{~s}$ for each point. The specific surface area was obtained by using the Brunauer-Emmett-Teller (BET) method. $\mathrm{N}_{2}$ adsorption-desorption isotherms were measured at liquid nitrogen temperature by a Micromeritics ASAP 2010. Before the measurements, the samples were evacuated at $200^{\circ} \mathrm{C}$ under vacuum $(0.2666 \mathrm{~Pa})$. High resolution TEM (HRTEM) was performed on a JEOL-JEM $2011 \mathrm{HR}(\mathrm{LaB})$ microscope operating at $200 \mathrm{kV}$.

The catalytic activity studies have been conducted in a synthetic gas bench using a synthetic gas mixture representative of the exhaust gases from diesel engines. The different experimental conditions are presented in Table 1.

Tab.1. Synthetic gas bench experimental conditions

\begin{tabular}{ccccccccc}
\hline & $\begin{array}{c}\mathrm{NO} \\
\mathrm{ppm}\end{array}$ & $\begin{array}{c}\mathrm{NO}_{2} \\
\mathrm{ppm}\end{array}$ & $\begin{array}{c}\mathrm{C}_{3} \mathrm{H}_{6} \\
\mathrm{ppm}\end{array}$ & $\begin{array}{c}\mathrm{CO} \\
\mathrm{ppm}\end{array}$ & $\begin{array}{c}\mathrm{CO}_{2} \\
(\%)\end{array}$ & $\begin{array}{c}\mathrm{O}_{2} \\
(\%)\end{array}$ & $\begin{array}{c}\mathrm{H}_{2} \mathrm{O} \\
(\%)\end{array}$ & $\begin{array}{c}\mathrm{N}_{2} \\
(\%)\end{array}$ \\
\hline Mix 1 & 300 & - & 200 & 300 & 5 & 10 & 5 & Balance \\
Mix 2 & 300 & 100 & 200 & 300 & 5 & 10 & 5 & Balance \\
Mix 3 & 300 & 100 & 200 & - & 5 & 10 & 5 & Balance \\
Mix 4 & - & 100 & 200 & 300 & 5 & 10 & 5 & Balance \\
\hline
\end{tabular}

The carrot $(\mathrm{d}=2.54 \mathrm{~cm} ; \mathrm{L}=2.6 \mathrm{~cm})$ was placed inside a stainless steel reactor, which itself was positioned inside an oven reaching temperatures up to $500^{\circ} \mathrm{C}$. Two thermocouples were available to follow the reaction temperature at the inlet and the outlet of the catalyst. The total flow was fixed at $11.8 \mathrm{~L} \cdot \mathrm{min}^{-1}$ resulting in a gas hourly space velocity (GHSV) of 55,000 $\mathrm{h}^{-1}$.

Catalysts were evaluated in terms of oxidation capacity and NO conversion for temperatures ranging from $50^{\circ} \mathrm{C}$ to $500^{\circ} \mathrm{C}$. Exhaust gas composition before and after the reactor were characterized by an environment S.A. analyzer composed of a set of modules. Among them, the TOPAZE 32M module allowed $\mathrm{NO}, \mathrm{NO}_{2}$ and total $\mathrm{NOx}$ measurement thanks to a 
chemiluminescence analyzer. A MIR2M module was composed of an IR spectrogram, for the measurement of $\mathrm{H}_{2} \mathrm{O}, \mathrm{CO}$ and $\mathrm{CO}_{2}$ molar fractions, and a magnetic sensor, for the $\mathrm{O}_{2}$ molar fraction measurement. At last, a flame ionization detector (FID), present in the GRAPHITE 52M module was used for measuring total HC.

\section{Results and Discussion}

\subsection{Characterization of the catalysts}

From TEM (Fig.1.), on both fresh and aged catalysts, only alloys of Pt-Pd are identified. HRTEM was performed, but neither Pt nor Pd was identified independently. Furthermore, EDS was performed (not shown here), on two samples: the stabilized one $\left(740 \_4 \mathrm{H}\right)$ and the 950_4H, respectively. On both samples, the same $\mathrm{Pt} / \mathrm{Pd}$ ratio is always observed irrespective of the targeted zones $\left(20 \mathrm{~nm}^{2}\right.$ and higher). From the Fig.1., one also observes that the aging of these particles leads to a sintering of the initial alloy and thus to a reduction of the contact surface of the active phase, resulting in a global decrease of the specific activity of the catalyst. XRD patterns also reveal the presence of support sintering (Fig. 2.). These results are in agreement with those found in the literature [6,7]. The textural parameters for the studied catalysts are given

by $S_{\mathrm{BET}}$ measurements and porous volume. The $\mathrm{S}_{\mathrm{BET}}$ are found to be $83,59,54$ and $51 \mathrm{~m}^{2} \cdot \mathrm{g}^{-1}$ for 750_4H, 850_10H, 850_24H and 950_4H respectively, which is consistent with the literature when the catalysts are aged at different high temperatures $[8,9]$. 


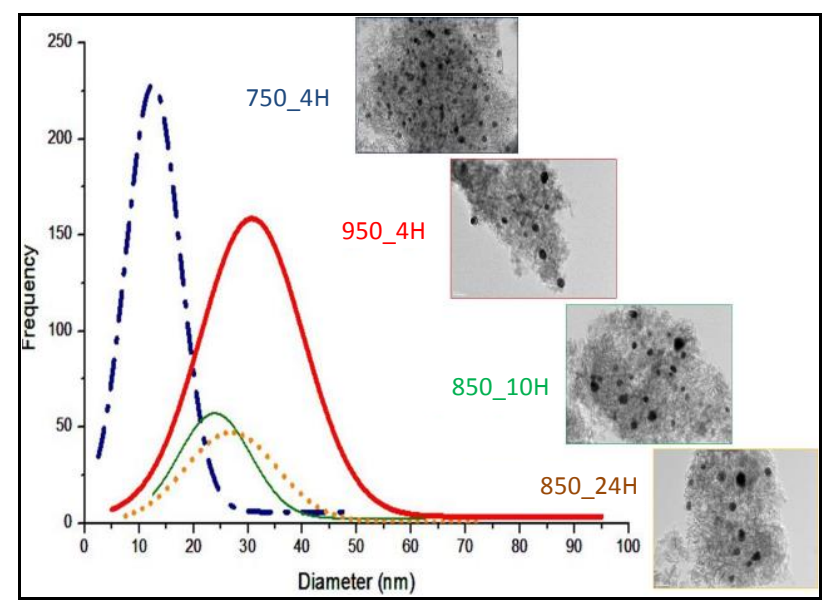

Figure 1 - Evolution of the particle distribution with aging procedures.

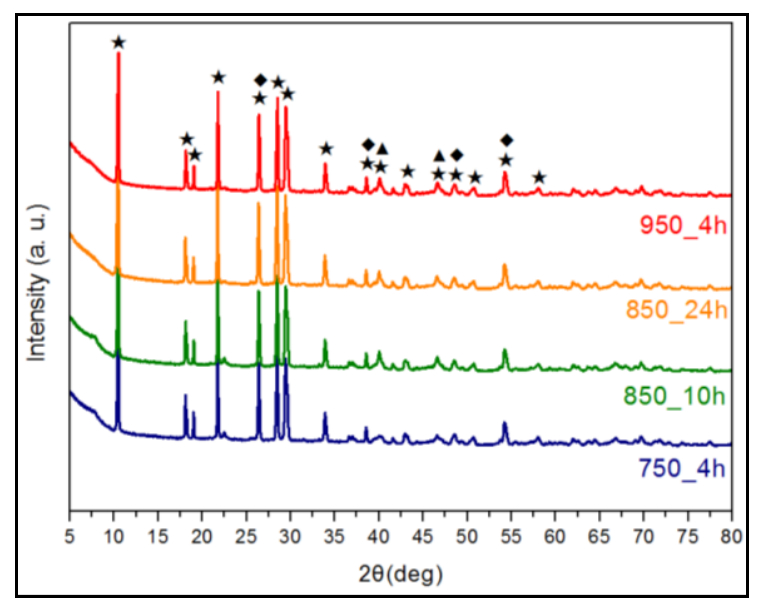

Fig. $2 \mathrm{X}$-ray diffractograms of the reference catalyst and aged catalysts

* Cordierite (ICDD 00-012-0303) $\boldsymbol{\Delta}$ Pt/Pd (ICDD 01-072-28-38) Aluminum (ICDD 01-070-3319)

In conclusion, the characterizations of the catalyst show that most of the active phase is an alloy of Pt-Pd supported on alumina. The analyses of aged catalyst reveal an increase of the alloy size, a support sintering and quantified the diminution of the catalyst specific surface area.

\subsection{Aging effect on DOC catalyst}

Four different light-off experiments are performed on 750_4H, 850_10H, 850_24H and 950_4H catalysts respectively. Compared to Mix 2, which is a representative mixture (with $\mathrm{NO} / \mathrm{NO}_{2}=3$ ) of the exhaust gases prior to the DOC in the specific DOC/DPF/SCR technology, the Mix 1 contains only $\mathrm{NO}$ in terms of $\mathrm{NO}_{x}$. The results are presented in Fig. 3. From Mix 1 and Mix 2, it can be noted that the aging has a negative effect on both hydrocarbon (Figs. 3a \& 3d) and CO oxidation (Figs. 3b \& 3e). From Fig 3a and 3b, one can conclude that the light off temperatures of hydrocarbon shifts to higher temperature with the aging severity which is agreement with the literature [9]. This result can be explained by the sintering of the particles of the aged catalysts, hindering optimal catalytic activity [10]. 

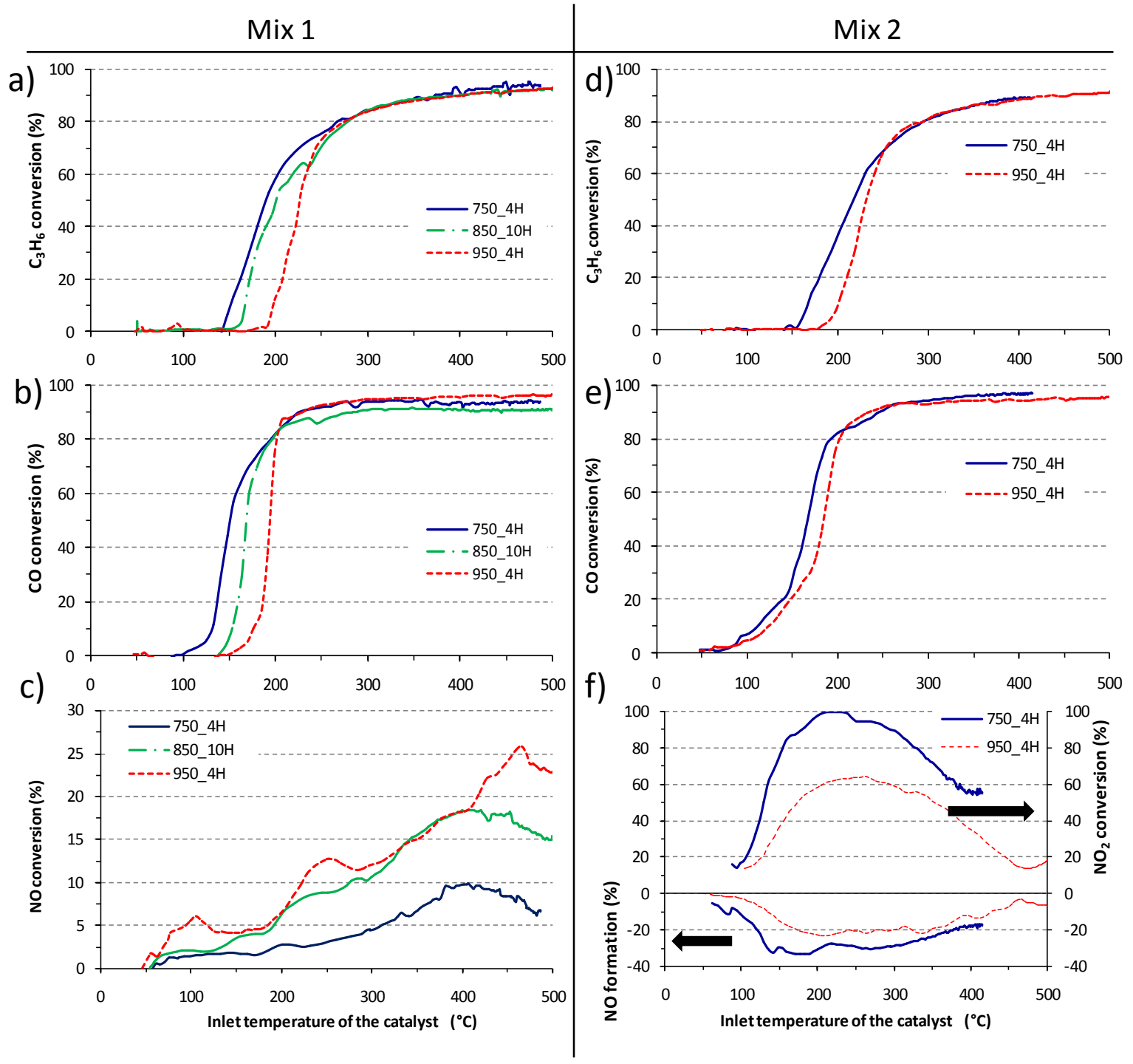

Fig

ure 3: Evolution of concentration of $\mathrm{C}_{3} \mathrm{H}_{6}, \mathrm{CO}, \mathrm{NO}$ and $\mathrm{NO}_{2}$ for Mix 1 and Mix 2 versus temperature for fresh and aged catalysts.

Indeed the average particle size was $12 \mathrm{~nm}$ for $750 \_4 \mathrm{H}, 24 \mathrm{~nm}$ for $850 \_10 \mathrm{H}$ and $31 \mathrm{~nm}$ for 950_4H. An opposite result is found for NO oxidation (Fig. 3c) which increases with the aging effect. This result is in agreement with the literature, since bigger $\mathrm{Pt} / \mathrm{Pd}$ particles favor NO oxidation [11], Hovewer, when only NO as NOx is present in the feed an opposite trend is observed [12,13]. Moreover for both fresh and aged catalysts, in Mix $1, \mathrm{NO}_{2}$ is not detected at low temperature until $\mathrm{CO}$ is oxidized. Schmeisser et al. [14] found that reducing agents in the lean feed such as $\mathrm{CO}$ and $\mathrm{C}_{3} \mathrm{H}_{6}$ hindered $\mathrm{NO}_{2}$ formation as long as they were present. Similar results have been also found in a DPNR in lean gas conditions [15]. 
On Fig. 3f, both $\mathrm{NO}$ and $\mathrm{NO}_{2}$ conversion are presented. In these conditions $\mathrm{NO}_{2}$ is reduced in NO, through reactions implying $\mathrm{CO}$ (see part 3.3). Reactions between $\mathrm{C}_{3} \mathrm{H}_{6}$ and NOx are not clearly identified in our experiments. Above $250^{\circ} \mathrm{C}$, where the contribution of $\mathrm{O}_{2}$ in $\mathrm{CO}$ oxidation is more important, the $\mathrm{NO}_{2}$ conversion is reduced and the $\mathrm{NO}_{2} / \mathrm{NO}$ ratio is increasing while keeping very low values (below 15\%) with a view to optimal SCR activity (Figure not shown). In Fig 3f, the positive effect of aging on NO oxidation in representative mixture is quite clear. This might be principally due to the improved $\mathrm{NO}$ oxidation by $\mathrm{O}_{2}$, favored by bigger $\mathrm{Pt} / \mathrm{Pd}$ particles.

\subsection{On the effect of the feed composition and aging on the catalytic performance of DOC}

In order to elucidate the effect of gas composition on the catalytic activity of DOC, Mix 3 and Mix 4 are added to the analysis process (Tab.1.). In Mix 3, CO is removed from the feed and in Mix 4, NO is removed (Fig 4). As expected, the aging negatively affects the catalyst performance on the oxidation of $\mathrm{C}_{3} \mathrm{H}_{6}$ and $\mathrm{CO}$. However, an improvement of the NO oxidation performance with the aging is observed when only NO is used in the feed (Mix 1). These behaviors are directly linked with the sintering of the Pt/Pd particles as already discussed above. In Fig. $4 \mathrm{~b}$ and $4 \mathrm{e}$, the conversion of $\mathrm{CO}$ is presented as a function of temperature and for different mixtures for $750 \_4 \mathrm{H}$ and $950 \_4 \mathrm{H}$, respectively. One can see that both for fresh and aged samples, the $\mathrm{CO}$ conversion is enhanced when $\mathrm{NO}_{2}$ is present in the feed (Mix 2 and Mix 4) due to an interaction which was already described in the literature $[14,15]$. The reaction is limited by the concentration of $\mathrm{NO}_{2}$, nearly totally converted (see fig. 3.f) when $30 \%$ of $\mathrm{CO}$ is converted (i.e., $100 \mathrm{ppm}$ of reactant transformed). The comparison of NO transformation between Mix 2 and Mix 3 (same mixture with and without CO, respectively), from Figs. 4c and 4f (fresh and aged catalyst, respectively), leads to the conclusion that NO formation is enhanced below $150^{\circ} \mathrm{C}$ when $\mathrm{NO}_{2}$ is reacting with $\mathrm{CO}$. 

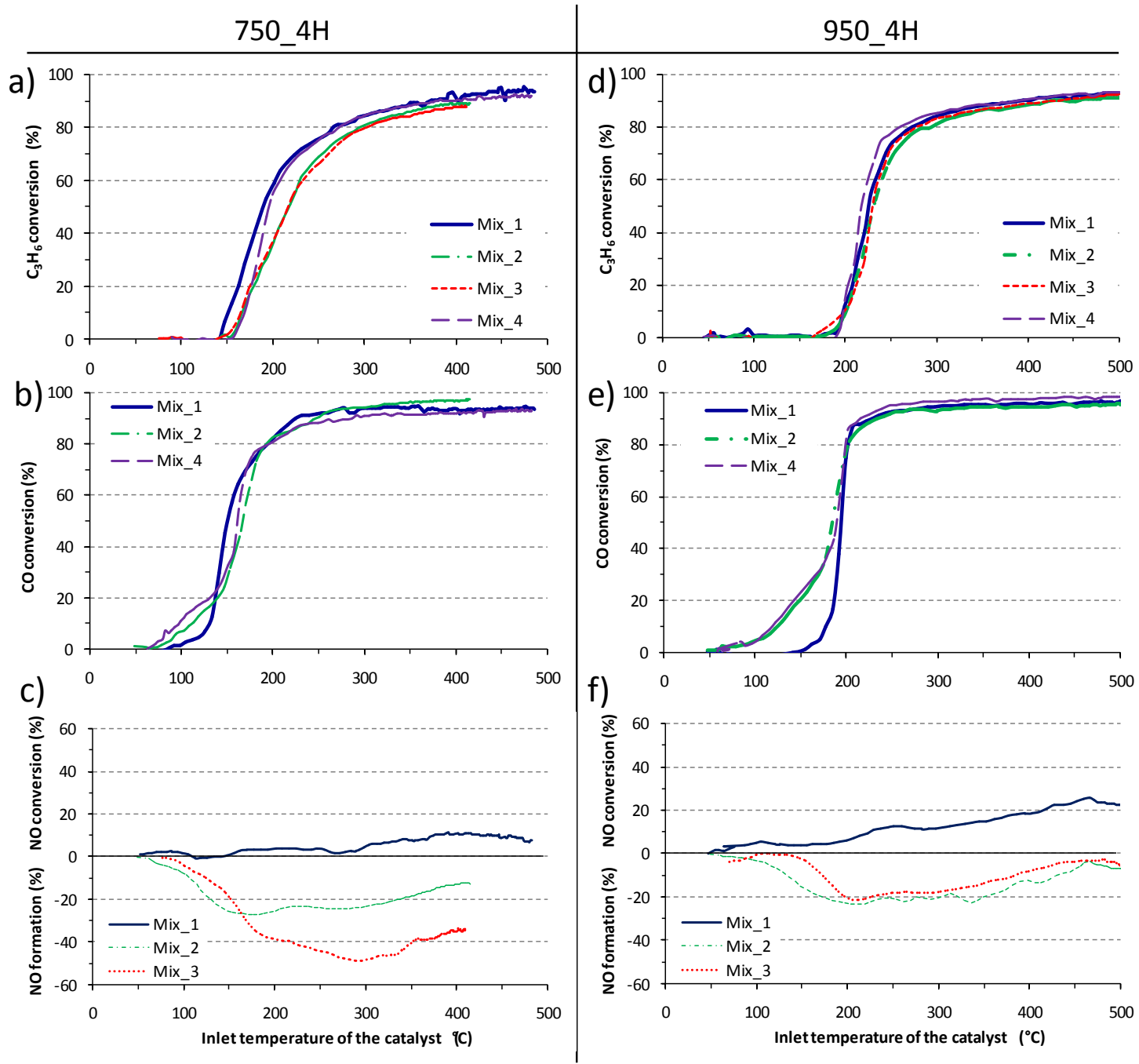

Figure 4: Effect of gas composition on the evolution of $\mathrm{CO}, \mathrm{C}_{3} \mathrm{H}_{6}, \mathrm{NO}$ and $\mathrm{NO}_{2}$ for fresh $\left(750 \_4 \mathrm{H}\right)(\mathrm{a}, \mathrm{b}, \mathrm{c})$ and aged catalysts $\left(950 \_4 \mathrm{H}\right)(\mathrm{d}, \mathrm{e}, \mathrm{f})$

The $\mathrm{C}_{3} \mathrm{H}_{6}$ conversion is presented in Figs. $4 \mathrm{a}$ and $4 \mathrm{~d}$. Results show, for $750 \_4 \mathrm{H}$ catalyst, an inhibiting effect, already observed in previous studies [15], when $\mathrm{NO}$ and/or $\mathrm{NO}_{2}$ are present in the feed. This latter is attributed by competition between $\mathrm{NO}, \mathrm{NO}_{2}$ and $\mathrm{C}_{3} \mathrm{H}_{6}$ for oxidation sites [11,17]. The difference between the inhibiting effect caused by $\mathrm{NO}_{2}$ and $\mathrm{NO}$ additions (Mix 1/Mix 4) suggest a stronger adsorption of $\mathrm{NO}_{2}$ than $\mathrm{NO}$ around $150^{\circ} \mathrm{C}$. These conclusions are not so clear for 950_4H catalyst, because of the sintering of the particles sizes and then the decrease of active sites number leading to a shift of about $30^{\circ} \mathrm{C}$ on the start of the light off curve. However, above $250^{\circ} \mathrm{C}$ there is almost no difference for both $\mathrm{CO}$ and $\mathrm{C}_{3} \mathrm{H}_{6}$ conversion since there are still enough active sites. From Figs. $4 \mathrm{c}$ and $4 \mathrm{f}$, one can conclude that whereas the NO 
oxidation is favored with 950_4H catalyst because of the sintering when only NO is present in the feed (Mix 1), the NO formation is lowered due less lower reactivity of $\mathrm{NO}_{2}$ with $\mathrm{CO}$ when the catalysts are aged.

\section{Conclusion}

In this work, a structure reactivity study of fresh and aged DO catalysts in changing the pollutants in feed was presented. It clearly showed that thermal aging pronouncedly impacted the overall oxidation activities of the catalysts. The decrease in activity was very large at low temperature $\left(<200^{\circ} \mathrm{C}\right)$ whereas almost no difference was observed at high temperatures. The thermal aging was more important for $\mathrm{NO}$ oxidation than for $\mathrm{CO}$ or hydrocarbon oxidation at low temperature leading then to a low production of $\mathrm{NO}_{2}$ and a lower SCR efficiency. Thus, this justified the development of new DOC systems in order to meet the future regulations on pollutants.

\section{References}

1. A. Russell and W. S. Epling, Catal. Reviews: Science and Eng, 53 (2011) 337-423

2. A. Manigrasso, N. Fouchal, P. Darcy, P. Da Costa, 191 Catal today (2012) 52-58

3. T. Kolli, T. Kanerva, M. Huuhtanen, M. Vippola, K. Kallinen, T. Kinnunen, T. Lepistö, J. Lahtinen, R. L. Keiski, Catal. Today 154 (2010) 303-307

4. A. Morlang, U. Neuhausen, K.V. Klementiev, F.-W. Schütze, G. Miehe, H. Fuess, E.S. Lox, Applied Catal. B: Env. 60, (2005) 191-199

5. A. Grossale, I. Nova, E. Tronconi, J. Catal. 265 (2009) 141-147

6. W. Hauptmann, M. Votsmeier, J. Gieshoff, A. Drochner, H. Vogel, Applied Catalysis B: Env. 93 (2009) 22-29

7. M. Salaün, A. Kouakou, S. Da Costa, P. Da Costa, Applied Catal B: Env. 88 (2009) 386-397

8. D. Adouane, S. Capela, P. Da Costa, Topics in catalysis 56 (2013) 45-49

9. M.H.Wiebenga, C.H. Kim, S.J. Schmieg, S.H.Oh, D.B.Brown, D.H.Kim, J.H.Lee, C.H.F.Peden, Catal. Today 184 (2012) 197-204

10. M. Adamowska, V. Lauga, P. Da Costa, Topics in catalysis 56 (2013) 267-272

11. E. Xue, K. Seshan, J.R.H. Ross, Applied Catal B: Env 11 (1996) 65-79

12. J.Kim, C. Kim, S.J. Choung, Catal. Today 185 (2012) 296-301

13. J. Li, A. Kumar, K. Kamasamudram, N. Currier, A. Yezerets, Catal. Today 258 (2015) 169174

14. V. Schmeisser, J. de Riva Perez, U. Tuttlies, G. Eigenberger, Top. Catal. 42-43 (2007) 15

15. C.-N. Millet, R. Chedotal, P. Da Costa, Applied Catal. B: Env., 90 (2009) 339-346

16. K. Irani, W. S. Epling, R. Blint, Applied Catal. B: Env., 92 (2009) 422-428

17. X. Auvray, L. Olsson, Applied Catal. B:Env. 168 (2015) 342-352 